\title{
PEDAGOGICAL-PSYCHOLOGICAL APPROACHES TO THE PROFESSIONAL PREPARATION OF THE FUTURE MUSIC TEACHER
}

\author{
Umidjon Yuldoshevich Yuldoshev \\ Senior Lecturer, Phd Tashkent State Pedagogical University Tashkent, Uzbekistan
}

\section{ABSTRACT}

This article discusses the requirements for modern music education, pedagogical conditions for improving higher music education, pedagogical techniques, pedagogical communication and the peculiarities of pedagogical training of future music teachers and pedagogical-psychological approaches.

KEYWORDS:- Music education, higher music education, practical performance, analytical-theoretical, talent, action strategy, continuing education, pedagogical competence, psychology, pedagogical communication.

\section{INTRODUCTION}

As a result of the growing prosperity of our socio-cultural life, it can be observed that in our society there is a growing interest in professions in the field of culture and art. This requires a higher level of professionalism and knowledge of specialists trained in these areas. In turn, this situation has led to the formation of new relationships in the system of music education, and the requirements for the professional level of trained professionals are growing day by day.

Article 9 of the Law on Education states that "the education system of the Republic of Uzbekistan is unified and continuous". This normative document substantiates the responsibility of all subjects of education, including highly qualified personnel trained in accordance with the principle of continuity in higher music education, to ensure the effective operation at all levels.

\section{THE MAIN FINDINGS AND RESULTS}

Music education is the process and result of the acquisition of musical knowledge, skills and abilities, and involves the mastery of musical phenomena in practical performance or analytical-theoretical. It is important that the future music teacher has a deep understanding of the social nature of the task of mastering, developing and transmitting to the younger generation the samples of musical experience accumulated in society.

It is the responsibility of the music teacher of the secondary school to select the most talented children, to organize special classes with them, to direct them to music and art schools. Therefore, one of the priorities is to provide music education with highly qualified teachers.

Annex 1 to the Decree of the President of the Republic of Uzbekistan Sh.Mirziyoyev dated February 7, 2017 "On the Strategy for further 
CURRENT RESEARCH JOURNAL OF PEDAGOGICS 2(10): 56-61,

October 2021 DOI: https://doi.org/10.37547/pedagogics-crjp-02-10-11

ISSN 2767-3278

(C)2021 Master Journals

\section{Crossref doi) gr Google}

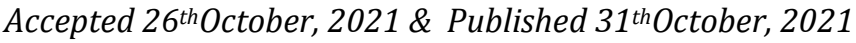

development of the Republic of Uzbekistan" Improving the quality and efficiency of higher education institutions on the basis of education ", he said.

In order to fulfill these tasks, a number of measures are ahead of higher music education. In particular, all state educational standards, curricula and qualification requirements in higher education are currently being reviewed and improved in terms of new approaches. The main emphasis in the training of future music teachers is on ensuring their professional and pedagogical competence, the widespread introduction of advanced pedagogical technologies and recognized foreign methods in teaching practice, and thus the training of competitive professionals.

The pedagogical practice of students is also a big task, which allows to predict and correct the level of future professional training, taking advantage of the opportunity to apply the acquired theoretical knowledge in practice. In addition, the pedagogical and psychological training of students is important, the ability to organize pedagogical communication with students at the required level, the ability to effectively use the necessary pedagogical skills in practice will be developed.

At the same time, "Theoretical analysis of the educational process, the study of the experience of advanced teachers, the division of the lesson into different stages also gives positive results" [3].

Today's music teacher is able to consistently use the opportunities of modern pedagogical and information technologies to instill in students a wide range of knowledge and skills in the field of national and world music, to develop the ability to listen to works of high artistic level and educational value. they need to have a specialist who nurtures a musical taste.
In music education, the task of "acquainting" students with music has changed, and now the task is to create more opportunities for each student to expand their artistic potential, to listen to musical works selectively, to express analytical opinions about them. The realization of this pedagogical goal imposes a greater responsibility on the music teacher, his spiritual and creative activity.

These requirements include, first of all, professional knowledge and pedagogical skills of a music teacher, performance potential, changes in music art and pedagogy, the ability to analyze innovations in terms of modern requirements, fluency in foreign languages and work with scientific literature, increase the effectiveness of training. - free, full use of communication technologies.

Second, regular self-study, initiative, organization, the ability to establish a positive, positive-psychological relationship with the teaching staff and students, the need to have the skills to be ready for all pedagogical requirements.

In the professional training of music teachers, the main focus is on the results of pedagogical work. Theoretical knowledge acquired in the course is reflected in practice, ie in various forms of musical and aesthetic activity of students, and is aimed at increasing the musical knowledge of students through various forms and methods of work, the formation of artistic and aesthetic taste in them (see drawing).

Methods of teaching and educating music - the interaction between the participants of the educational process, through musical activities should lead to the acquisition of knowledge, skills and abilities of the student and the development of musical and aesthetic qualities. Methods of teaching and educating music reflect the holistic creative nature of the educational process. 
CURRENT RESEARCH JOURNAL OF PEDAGOGICS 2(10): 56-61,

October 2021 DOI: https://doi.org/10.37547/pedagogics-crjp-02-10-11

ISSN 2767-3278

(C)2021 Master Journals

\section{Crossref doi) gr Google}

Accepted $26^{\text {th }}$ October, 2021 \& Published $31^{\text {th }}$ October, 2021

It is helpful for a music teacher to know different ways to behave in a good, businesslike mood. These include expecting students to be motivated for a well-organized lesson, creating satisfaction from the cheerful part of the lesson, an exciting piece of music, and the fun of the lesson topic.

In particular, "in the current social environment, where there is a tendency to mix Eastern and Western cultures, it is important to arouse students' interest in our national music and create a positive atmosphere". It is desirable that these features be systematically formed in students.

Of course, a music teacher doesn't just go into a classroom in 45 minutes to "catch up" or get a clear singing. One or more lessons are just one part of the process of introducing students to the art of music. Therefore, it is necessary not only to sing in a literate and expressive way, but also to be able to express one's thoughts and dreams, imagination, experiences, as well as attitudes through it.

Positive psychological qualities for high-level organization of the lesson: distribution of attention - control of the quality of students' performance in both singing and group singing, transfer of attention - free transition from singing to mastering theoretical materials or listening. "Every teacher-educator, before entering the pedagogical activity, must first have the skills to organize it independently, to create personal experiences".

It is expedient that music education today be organized on the basis of "interaction" rather than "pedagogical influence", and the pedagogical competence of the teacher is crucial in this.

The teacher must "prepare" himself for the lesson before each lesson. To do this, it is necessary to get rid of all unnecessary stimuli (fantasies and thoughts) by the power of will before the lesson. That is, it is expedient to create a "working pedagogical vacuum" around themselves, to regulate the nerves, to create a positive mood.

In preparation for a music lesson, the teacher should estimate his or her capabilities and organize the work on this basis, taking into account where the piece of music to be sung or listened to is a little empty, and where special emphasis should be placed. Measuring this type of opportunity determines a teacher's physical condition, level of professional training, and pedagogical ability. The amount of integrity of personal and professional (professional) qualities indicates the limits and range of pedagogical capabilities of a music teacher. As a result, the professional training of a music teacher becomes a huge motivating factor in school work.

In addition, it is important for the teacher to follow the laws of reflection, to analyze their own behavior: that is, from time to time it is advisable to videotape a particular lesson and analyze the material from beginning to end.

The teacher's tolerance and optimism are important in the lesson. After all, musical activity is an activity that is carried out through experience and emotion. If the teacher has set himself the goal of helping the student in the learning process, then the artistic tasks assigned to the student will bring him closer to the teacher.

The music teacher's approach to the class community is highlighted in science. The teacher's stable-positive style is manifested in caring for students, helping in times of difficulty, a work-positive reaction to shortcomings in learning and behavior, and calmness in communication with children. A teacher belonging to this group is characterized by a bright pedagogical talent, respect for children 
CURRENT RESEARCH JOURNAL OF PEDAGOGICS 2(10): 56-61,

October 2021 DOI: https://doi.org/10.37547/pedagogics-crjp-02-10-11

ISSN 2767-3278

(C)2021 Master Journals

\section{Crossref doi) 81 Google}

Accepted $26^{\text {th }}$ October, 2021 \& Published $31^{\text {th }}$ October, 2021

and can achieve high pedagogical efficiency, performance results.

A teacher with a passive-positive pedagogical style is characterized by an ambiguous emotional-positive attitude towards children. Such a teacher may manifest in team performance by not analyzing the quality of each student's performance, failing to correct deficiencies, and not encouraging students to perform at an excellent level (see picture).

The unstable style in the teacher's attitude towards children is manifested by situational dependence and general emotional propensity. Teachers belonging to this group are sometimes bound by their moods and experiences. It is recommended that future music teachers implement pedagogical communication in a sustainable positive way.

Since the language of music is the language of emotions, communication has great potential in accurately expressing experiences and situations, introducing students to the mysterious world of musical tones, and conveying to them the artistic idea of a work being studied, listened to, or analyzed.

The question arises - how does a pedagogical performance differ from a concert performance? It does not differ in terms of sound, but it certainly differs as a teaching performance, in terms of its delivery to the listener, its interpretation, its emphasis on certain points. In this regard, the technique of pedagogical performance is reflected in the effective organization of the learning process by the teacher. It is a set of performance skills and abilities used by the teacher in the implementation of the performance repertoire at a high level of requirements.

Also, pedagogical techniques allow the teacher to choose the right way of behaving when communicating with students. Behavior, style of communication with students, diction, facial expressions, correct choice of gestures, all this is part of pedagogical techniques.

One of the pedagogical factors that ensure the success of musical activity is the art of communication. They consist of several views.

1. Flexibility in solving artistic tasks. This means the ability to quickly adapt to the team of students when performing performance activities with the class team. After all, this opportunity is an important factor in the success of interactive music activities.

2. Being emotionally compromised. Various psychological and emotional situations are encountered during the course. Sometimes there are mood-depressing, negative situations: if they are less noticeable, ignoring them, if they are bigger, you need to calmly address the issue and move quickly to the topic analysis.

3. Compassion. The mood of the students is important in the successful organization of a music lesson. Therefore, it is important to monitor the mood of each student before and during the lesson and, if necessary, to support and sympathize with them.

4. Be prepared for problematic situations. Different situations can be encountered in the effective organization of student interaction. Problematic situations should be resolved lightly.

5. Subject-subject communication in communication.

Exercises that simulate situations that require emotional states, which are necessary in the process of pedagogical communication, can be performed with students. At the same time, students can be offered situations, analyze the answers received and select pedagogically 
CURRENT RESEARCH JOURNAL OF PEDAGOGICS 2(10): 56-61,

October 2021 DOI: https://doi.org/10.37547/pedagogics-crjp-02-10-11

ISSN 2767-3278

(C)2021 Master Journals

\section{Crossref doi) google}

Accepted $26^{\text {th }}$ October, 2021 \& Published $31^{\text {th }}$ October, 2021

acceptable options.

The first situation. The lesson has begun. You (the teacher) have taken over your desk. The door opens. You look at the student who comes in and say, "Sit down quickly" or "I didn't expect it", in a disgruntled tone, "Are you sharing an opinion", "Are something wrong?" in the case of "goodness!" you might say.

The second situation. You call the student to the board, he says he didn't do the task. Then you say sadly, "I understand, you're uncomfortable" and then you say, "It's not right" and then you keep quiet for a while, "What happens now, how do you explain that?" you can say, or wonder, "How many times is this?", or indifferently, "I don't care anymore".

It is expedient to cite situations that justify themselves in solving these tasks. All situations can be performed by students in the role of teacher or student and the results can be compared. Importantly, it is possible to work on the mimicry options required in certain situations by determining what effects these reactions have on the partner.

The teacher must pay close attention to his / her pedagogical skills, intellect and culture, check the level of his / her ability to perform his / her professional duties, and regularly look for optimal ways to penetrate the minds and hearts of students.

\section{Conclusion}

After all, a teacher not only equips his students with knowledge, but also influences them with his behavior. His intellect and culture, his honesty and humanity, his spiritual qualities should be accepted as a standard by the students. The teacher should also be able to determine the development prospects of the student body and each of its members.

Formation of the above-mentioned professional pedagogical qualities and qualities in future music teachers - creates ample opportunities for the successful implementation of the tasks set out in the Action Strategy for the further development of the Republic in higher music education.

\section{REFERENCES}

1. Decree of the President of the Republic of Uzbekistan "On the Action Strategy for further development of the Republic of Uzbekistan". Annex 1: "Action Strategy for the five priority areas of further development of the Republic of Uzbekistan for 20172021." People's Word newspaper. February 8, 2017 issue and Internet resource: www.lex.uz.

2. Bahriev A.R. Socio-psychological features of the formation of national musical perceptions in students. Psixol.f.n. diss-ya. T., 2004. P.51.

3. Karimova D.A. Innovative technologies of music teaching. Study guide. T., 2011. B.21

4. Axmedjanov M.M. and others. Pedagogical skills., 2010. P.13.

5. Law of the Republic of Uzbekistan "On Education". Bulletin of the Oliy Majlis of the Republic of Uzbekistan, 1997, No. 9.

6. Yuldoshevich, Y. U. (2020). THE MODEL OF PEDAGOGUE OF MUSIC AND TEACHERSTUDENT RELATIONSHIP IN MAKOM EDUCATION. Journal of Critical Reviews, 7(5), 1664-1676.

7. Yuldoshev, U. (2018). Problems of Choosing Methods and Technologies in Musical Pedagogics. Eastern European Scientific Journal, (2). 
CURRENT RESEARCH JOURNAL OF PEDAGOGICS 2(10): 56-61,

October 2021 DOI: https://doi.org/10.37547/pedagogics-crjp-02-10-11

ISSN 2767-3278

(C)2021 Master Journals

Crossref do) 81 Google

Accepted 26 $6^{\text {th }}$ October, 2021 \& Published $31^{\text {th }}$ October, 2021

8. Zarytska, A., Zhorniak, B., \& Rehulich, I. (2019). SCIENTIFIC-METHODICAL SYSTEM

FOR THE PROFESSIONAL QUALITIES

FORMATION OF MUSIC TEACHERS IN

PEDAGOGICAL COLLEGE. Sustainable development under the conditions of European integration. Part II, 97.

9. Omonov, Q., \& Karimov, N. (2020). Importance of Ancestoral Heritage. The American Journal of Social Science and Education Innovations, 2(09), 196-202.

10. Khudoyberdiyevich, D. A., \& Rakhmonqulovich, K. N. (2020). An incomparable book of a great scholar. Bulletin Social-Economic and Humanitarian Research, (6 (8)), 63-71. 